\title{
Cosmogenic analysis of glacial terrains in the eastern Canadian Arctic: a test for inherited nuclides and the effectiveness of glacial erosion
}

\author{
P. Thompson Davis, ${ }^{1}$ Paul R. Bierman, ${ }^{2}$ Kimberly A. Marsella, ${ }^{2 *}$ \\ Marc W. Caffeet, John R. Southon ${ }^{3}$ \\ ${ }^{1}$ Department of Natural Sciences, Bentley College, Waltham, MA 02454-4705, U.S.A. \\ ${ }^{2}$ Department of Geology, University of Vermont, Burlington, VT 05405, U.S.A. \\ ${ }^{3}$ Lawrence Livermore National Laboratory, Livermore, CA 94550 U.S.A.
}

\begin{abstract}
To determine the effectiveness of glacial erosion and the magnitude of cosmogenic nuclide inheritance from prior periods of cosmic-ray exposure, we measured the abundance of ${ }^{10} \mathrm{Be}$ and ${ }^{26} \mathrm{Al}$ in nine samples collected from bedrock, boulders and cobbles exposed by the retreat of Tumbling Glacier, Baffin Island, Canada. Most samples had nuclide concentrations so low that we were only able to set upper limits for nuclide abundance. Three boulders, two on a Neoglacial moraine of Tumbling Glacier that impounds Crater Lake and one on a roche moutonnée within the Neoglacial moraine loop, had nuclide abundances indicating no more than $900 \mathrm{yr}$ of exposure at the surface. Three bedrock samples, striated by Tumbling Glacier and exposed by ice retreat within the last $20 \mathrm{yr}$, have similarly low nuclide abundances. One bedrock sample, covered by Tumbling Glacier ice for some part of the Holocene but not eroded, allows us to estimate crudely the duration of Neoglaciation at our sample site (about $5450 \mathrm{yr}$ ) and to provide a lower limit on the erosion rate of Tumbling Glacier $\left(0.10 \pm 0.03 \mathrm{~mm} \mathrm{a}^{-1}\right)$. We analyzed two cobbles collected from the tops of roches moutonnées at Crater Lake; one cobble had the equivalent of $3000 \mathrm{yr}$ of exposure, the other $<900 \mathrm{yr}$.
\end{abstract}

\section{INTRODUCTION}

We are using in-situ produced cosmogenic nuclides to resolve the vertical and lateral extent of ice margins in the eastern Canadian Arctic during Wisconsinan glaciations. We measured ${ }^{10} \mathrm{Be}$ and ${ }^{26} \mathrm{Al}$ abundances in $>140$ samples of glacially molded bedrock and erratic boulders collected from the Pangnirtung Fiord area of Baffin Island (Fig. 1; Marsella, 1998). Our data suggest that late Wisconsinan (Stage 2) glaciation in the Pangnirtung Fiord area was much more extensive than previously believed (Davis and others, 1995, 1996a, b; Marsella and others, 1995, 1996; Marsella, 1998; Bierman and others, 1999).

Cosmogenic nuclide inheritance from prior exposure can produce erroneously old ages in both bedrock or boulder samples. To evaluate the likelihood of such inheritance in our Baffin Island dataset, we collected and analyzed seven samples, all of which were exposed from under Tumbling Glacier by ice retreat during the past 20 years. We collected samples from the striated tops of two roches moutonnées $(n=4)$, from cobbles sitting on top of each roche

\footnotetext{
* Present address: Department of Geology, Bates College, Lewiston, ME 04240-6084, U.S.A.
}

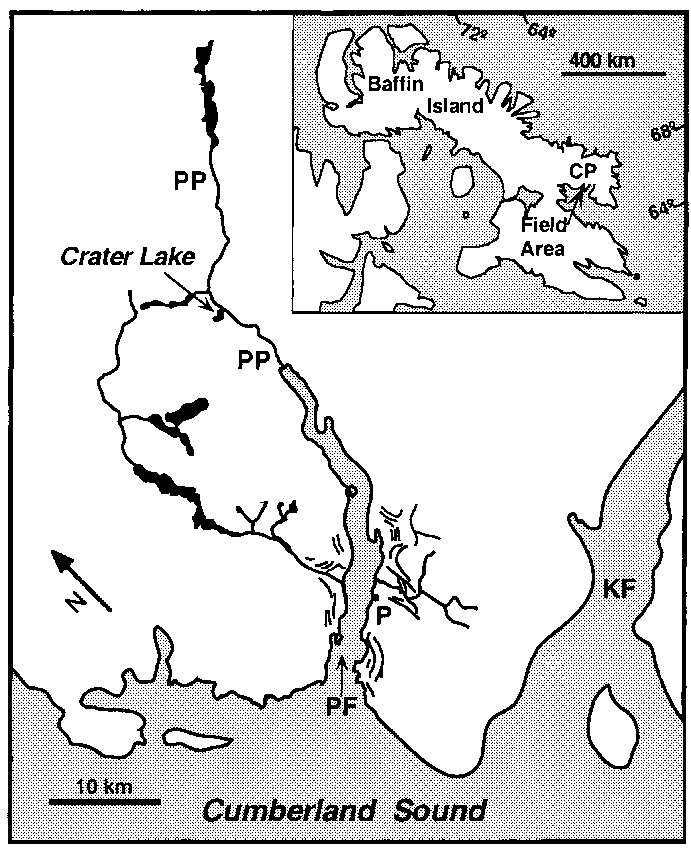

Fig. 1. Map showing Crater Lake in Pangnirtung Pass (PP) on Cumberland Peninsula (CP on inset), Pangnirtung hamlet $(P)$, Pangnirtung Fiord (PF) and Kingnait Fiord (KF). Thin line segments along the sides of Pangnirtung Fiord are late-Wisconsinan age Duval moraines. 

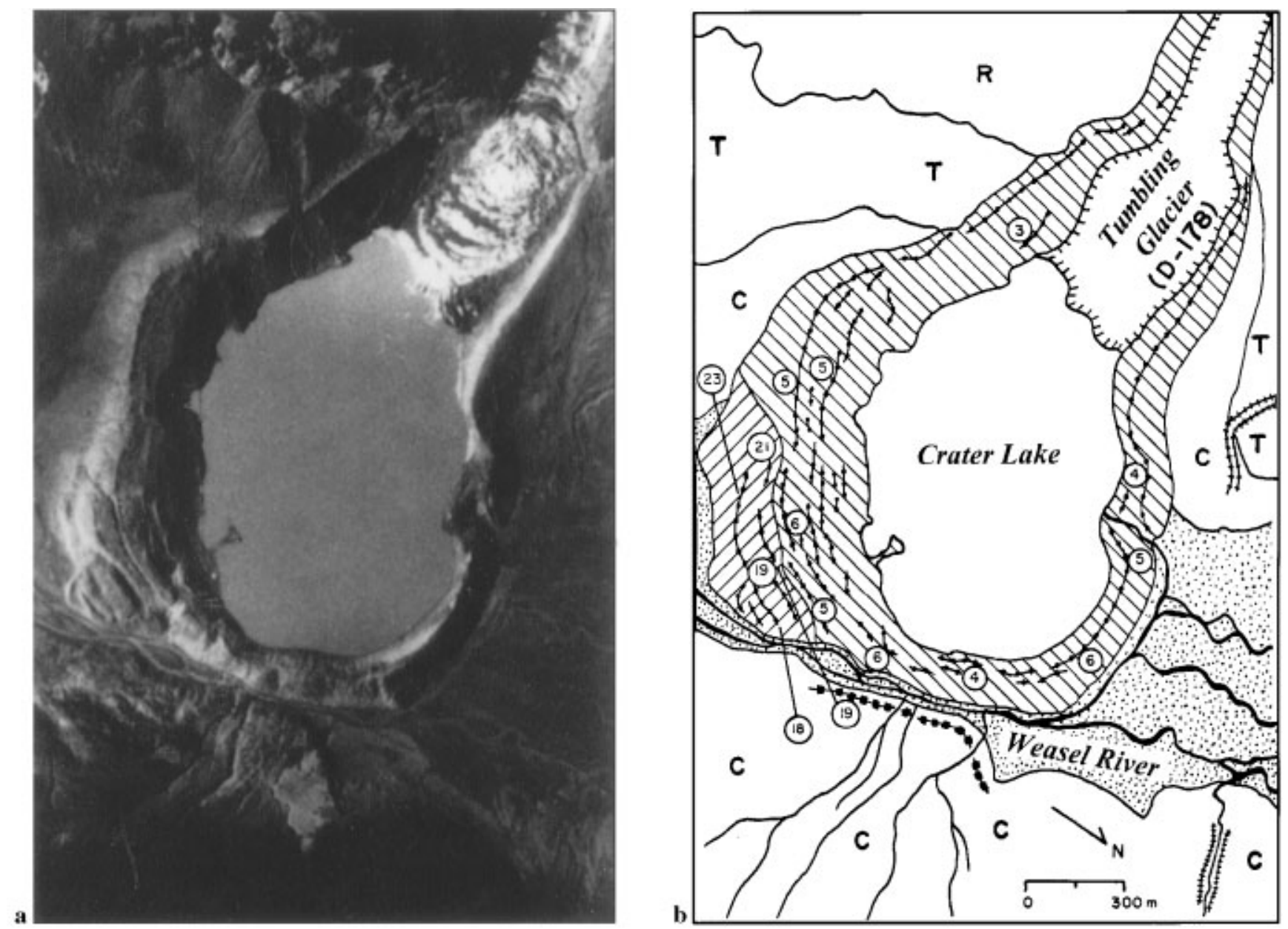

EXPLANATION

\section{Glacial Drift Sheets (Maximum $R$. Geographicum diameters in $\mathrm{mm}$ )}

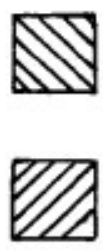

\section{Cumberland
Advance II \\ Cumberland Advance I}

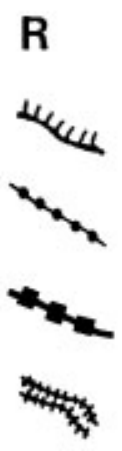

\section{Bedrock}

Glacier Margin

Moraine Ridge

Protalus Ridge

Debris Flow Levee

T Talus

\section{Colluvium}

(1.7) Alluvium

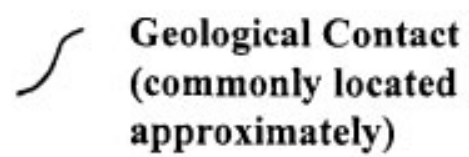

Stream (permanent or intermittent)

Fig. 2. Tumbling Glacier, Crater Lake and Neoglacial moraines. (a) Part of vertical air photograph showing bergs calving from Tumbling Glacier into Crater Lake (Government of Canada, A16817-29, 1959). (b) Moraines impounding Crater Lake. Lichenometric data (circled numbers are diameters in $\mathrm{mm}$ ) indicate at least two advances (Cumberland Advances I and II) occurred during the late Neoglacial, spanning about the last $400 \mathrm{yr}$. Protalus ridge originated from mass movements on valley side across Weasel River from Crater Lake and is probably late Wisconsinan in age.

moutonnée $(n=2)$ and from a boulder sitting between the sampled outcrops $(n=1)$. Because these samples were exposed from under the ice after 1976, they should contain nuclide abundances below the detection limit unless nuclides were inherited from a prior period of exposure. In addition, we sampled two boulders on the Neoglacial moraine of Tumbling Glacier, which impounds Crater Lake. Lichenometric studies (Davis, 1985) suggest that these moraine boulders should have no more than several hundred years of exposure (Fig. 2). This paper reports the results of our test.

\section{BACKGROUND}

Until recently, most workers believed that Pangnirtung Pass (Fig. 1) and most fiords along the east coast of Baffin Island were not glaciated during the late Wisconsinan (Thompson, 1957; Miller and Dyke, 1974; Andrews, 1975, 1987; Dyke, 1977, 1979; Ives, 1978; Dyke and Prest, 1987) and thus the late Wisconsinan ice margin is depicted well to the north of our sample site at Crater Lake by Dyke and others (1982). This view of limited ice extent in the eastern Canadian Arctic has 
been the major objection to an extensive Arctic ice sheet during the lateWisconsinan (Hughes and others, 1977; Denton and Hughes, 1981; Mayewski and others, 1981). However, Jennings (1993) and Jennings and others (1996) determined that late Wisconsinan glacial ice filled Cumberland Sound (Fig. 1), extending about $400 \mathrm{~km}$ beyond the late Wisconsinan ice margin shown in Dyke and others (1982). A more-extensive late Wisconsinan ice margin in the Cumberland Sound area is also consistent with the recognition of Heinrich events in the Labrador Sea (Andrews and others, 1994, 1995; Jennings and others, 1996).

Only very recently has accelerator mass spectrometry (AMS) radiocarbon dating begun to resolve the age of terrestrial Arctic landscapes (Abbott and Stafford, 1996). Although radiocarbon ages from lake-sediment cores in lowlands and floors of glacial valleys are consistent with late Wisconsinan ice cover (Short and others, 1985; Lemmen and others, 1988), some lake-sediment records from uplands in the Pangnirtung Fiord area indicate that higher areas may have been nunataks during the late Wisconsinan (Wolfe, 1996; Wolfe and Härtling, 1996). Our larger dataset of $>140$ cosmogenic nuclide exposure ages for the Pangnirtung Fiord area (Marsella, 1998; Bierman and others, 1999) suggests a long and complex burial and exposure history for upland surfaces, but does not rule out the possibility of cover by cold-based ice during the late Wisconsinan (cf. Hughes and others, 1977; Sugden, 1977; Sugden and Watts, 1977).

Although interpretations of lateWisconsinan ice margins in the Pangnirtung Fiord area have been contentious, there is general agreement that local glaciers on Baffin Island readvanced during Neoglaciation (Miller, 1973; Andrews and Barnett, 1979; Davis, 1980, 1985, 1987). The development of growth curves for Rhizocarpon geographicum s.l. on Baffin Island (Miller and Andrews, 1972; Miller, 1973; Andrews and Barnett, 1979; Davis, 1985) has allowed discrimination of multiple glacier advances during the last 3000-4000 yr. The most recent Neoglacial advances, which correlate with the Little Ice Age (Miller, 1973; Davis, 1985), are commonly the most extensive on Baffin Island and thus much of the earlier part of the Neoglacial record is obliterated. However, proxy climate records less prone to obliteration, such as lichenometrically dated debris-flow levées (Davis and Fabel, 1988) and radiocarbon-dated debris-avalanche sediments in a lake (Davis and Kihl, 1985), accord with multiple glacier advances during Neoglaciation.

Palynological analyses of lake-sediment cores from Baffin Island also indicate cooling during the last 4000-5000 yr, following a warmer early Holocene (Davis, 1980; Andrews and others, 1980, 1981; Short and others, 1985). Other continuous records of Holocene climatic change in the Pangnirtung area include analyses of diatoms in lake-sediment cores, which also indicate early Holocene warming followed by Neoglacial cooling (Wolfe, 1996; Wolfe and Härtling, 1996). The rapid retreat of glaciers and ice caps on Baffin Island during the past two decades is consistent with larger data bases that suggest global warming (Mann and others, 1998).

\section{SITE LOGATION}

The moraines impounding Crater Lake (Fig. 2) in southern Pangnirtung Pass all date to the latter part of the Little Ice Age (Cumberland Advances I and II) and probably obliter- ated earlier Neoglacial moraines, which are found fronting glaciers elsewhere in Pangnirtung Pass (Davis, 1980, 1985). When air photographs were taken of Pangnirtung Pass in 1959, Tumbling Glacier extended into Crater Lake. By 1976, Tumbling Glacier had retreated, but glacier debris or a floating ice tongue still extended beyond the near-vertical snout. However, by 1994, the margin of Tumbling Glacier had retreated sufficiently to expose a promontory of fresh, quartzrich gneissic bedrock extending across Crater Lake, about $100 \mathrm{~m}$ beyond the current ice margin (Fig. 3). The roches moutonnées, boulders, and cobbles exposed on this rock shelf, as well as two gneissic boulders cropping out on the Neoglacial moraine, are the focus of the study reported here.

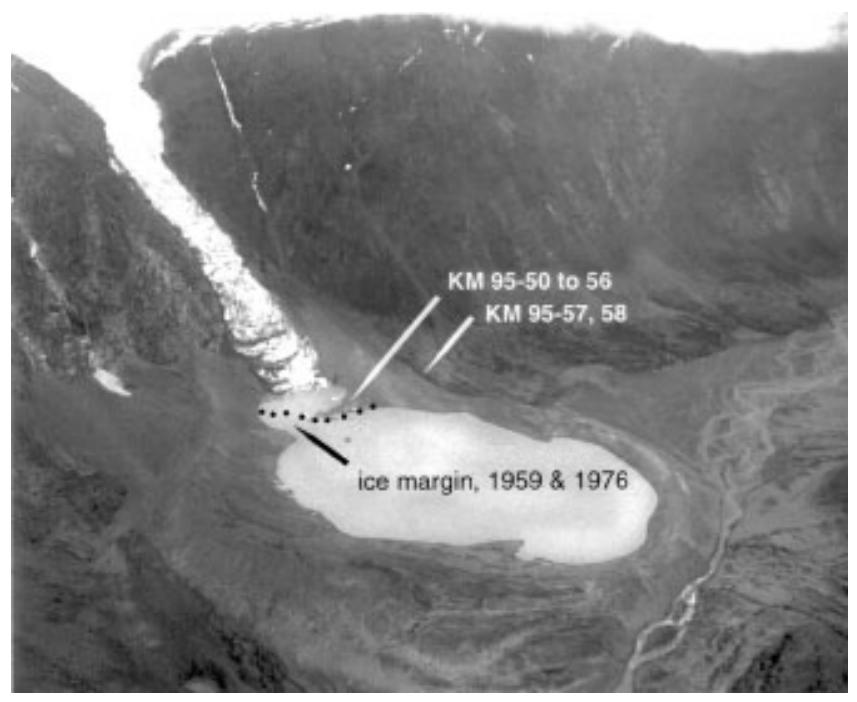

Fig. 3. Oblique air photograph (1994) looking northwest at snout of Tumbling Glacier, which has retreated about $100 \mathrm{~m}$ since 1976, exposing a promontory of roches moutonnées and overlying glacial boulders. Ice margin from 1959 (Fig. 2) and 1976 shown by dotted line. Numbered cosmogenic nuclide sample sites shown in more detail in Figure 4.

\section{METHODS}

We used hammers and chisels to sample the tops of freshly polished and striated bedrock and boulders, avoiding edges with steep sides. Sample thickness $(15-50 \mathrm{~mm})$ and topographic shielding were measured in the field. We used standard methods to purify quartz and chemically purify Be and Al (Kohl and Nishiizumi, 1992; Bierman and Gillespie, 1995).

Our laboratory procedure involved sample processing in batches of eight, one process blank and seven samples. For each sample, 26-43 g of quartz was dissolved, to which we added 250-300 $\mu \mathrm{g}$ of commercial Be carrier (SPEX brand), quantitatively. Stable $\mathrm{Al}$ was measured by ICP-OE (inductively coupled argon plasma spectroscopy, optical emission) in aliquots of solutions used to prepare targets for isotopic analysis. Reported measurements are averages of duplicate analyses made on two different dilutions, each corrected to three internal standards spanning the range of observed concentrations. Because sample quartz contained from 91$141 \mu \mathrm{g} \mathrm{g}^{-1}$ stable Al, no Al carrier was added except to the process blank. Process blanks contained only Al $(2000 \mu \mathrm{g})$ and $\mathrm{Be}(250-300 \mu \mathrm{g})$ and were subjected to the same chemical procedures as actual samples. 
Table 1. Isotopic data for Crater Lake samples, Baffin Island

\begin{tabular}{|c|c|c|c|c|c|c|c|}
\hline \multirow[t]{2}{*}{ Sample } & \multirow[t]{2}{*}{$\begin{array}{c}\text { Boron } \\
\text { F.O.M. }{ }^{2}\end{array}$} & \multirow{2}{*}{$\begin{array}{c}\text { Sample size } \\
\mathrm{g}\end{array}$} & \multirow{2}{*}{$\begin{array}{c}\text { Native Al } \\
\text { ppm }\end{array}$} & \multirow{2}{*}{$\begin{array}{l}\text { Measured } \\
{ }^{10} \mathrm{Be} /{ }^{9} \mathrm{Be} \\
\times 10^{-15}\end{array}$} & \multirow{2}{*}{$\begin{array}{l}\text { Measured } \\
{ }^{26} \mathrm{Al} /{ }^{27} \mathrm{Al} \\
\times 10^{-15}\end{array}$} & \multirow{2}{*}{$\begin{array}{c}\text { Blank-subtracted } \\
{ }^{10} \mathrm{Be} /{ }^{9} \mathrm{Be} e^{3,4} \\
\times 10^{-15}\end{array}$} & \multirow{2}{*}{$\begin{array}{c}\text { Blank-subtracted } \\
{ }^{26} \mathrm{Al} /{ }^{27} \mathrm{Al} l^{3,4} \\
\times 10^{-15}\end{array}$} \\
\hline & & & & & & & \\
\hline 67KM95-50 & 0.77 & 34.80 & 115 & $30.4 \pm 5.4$ & $5.1 \pm 1.8$ & $<18.5$ & $<7.1$ \\
\hline 67KM95-51 & 0.67 & 43.46 & 95 & $32.3 \pm 7.6$ & $6.4 \pm 3.8$ & $<21.4$ & $<11.4$ \\
\hline 69KМ95-52 & 0.79 & 43.69 & 91 & $55.8 \pm 5.3$ & $13.6 \pm 4.1$ & $<17.5$ & $<16.3$ \\
\hline 67KM95-54 & 0.88 & 35.59 & 95 & $77.2 \pm 9.9$ & $35.8 \pm 5.8$ & $42.5 \pm 12.4$ & $32.0 \pm 6.2$ \\
\hline 67KM95-55 & 0.89 & 37.60 & 93 & $42.2 \pm 5.2$ & $18.3 \pm 4.0$ & $<25.8$ & $14.5 \pm 4.6$ \\
\hline 69KM95-56 & 0.85 & 29.33 & 141 & $82.8 \pm 5.6$ & $45.9 \pm 8.9$ & $31.5 \pm 6.8$ & $37.6 \pm 9.6$ \\
\hline 67KM95-57 & 0.88 & 36.74 & 91 & $44.3 \pm 5.3$ & $14.1 \pm 3.8$ & $<28.0$ & $10.2 \pm 4.4$ \\
\hline 67KM95-58 & 0.83 & 40.41 & 98 & $48.1 \pm 9.9$ & $9.9 \pm 3.1$ & $<38.2$ & $<13.7$ \\
\hline Blank batch 67 & 0.61 & & & $34.7 \pm 7.5$ & $3.9 \pm 2.3$ & & \\
\hline Blank batch 69 & 0.80 & & & $51.3 \pm 3.8$ & $8.3 \pm 3.7$ & & \\
\hline
\end{tabular}

1 First two digits in sample ID indicate batch in which sample was run. A process blank is associated with each batch of seven samples.

${ }^{2}$ Boron figure of merit indicates the fraction of total gated counts attributable to ${ }^{10} \mathrm{Be}$; remaining counts are attributed to ${ }^{10} \mathrm{~B}$.

3 Ratio of batch-specific process blank subtracted from measured ratios of samples in each batch; errors propagated quadradically.

4 Less than values $(<)$ indicate that counting statistics were inadequate to define a finite ratio; we state upper limit of possible ratio at two standard deviations. Limit calculated by adding blank-subtracted ratio and two times the standard deviation of that ratio.

Ratios of ${ }^{10} \mathrm{Be} /{ }^{9} \mathrm{Be}$ and ${ }^{26} \mathrm{Al} /{ }^{27} \mathrm{Al}$ were measured for each sample and process blank using AMS at the Lawrence Livermore National Laboratory (LLNL). Each target was measured at least twice and compared to at least three analyses of LLNL laboratory standards. For Be, a correction was made for the interference caused by ${ }^{10} \mathrm{~B}$, an isobar of ${ }^{10} \mathrm{Be}$. This correction is based on the ratio of gated counts to total counts in a target spiked with B but known to contain only low levels of ${ }^{10} \mathrm{Be}$. When the boron correction is made, a $50 \%$ uncertainty on this correction is propagated quadratically. For all but two of our samples, more than $75 \%$ of the gated counts were attributed to ${ }^{10} \mathrm{Be}$; for the other two samples, $61 \%$ and $67 \%$ of the gated counts were attributed to ${ }^{10} \mathrm{Be}$ (F.O.M. [figure of merit], Table 1).
To estimate isotopic ratios in our nine samples, the ratio measured in the appropriate process blank was subtracted from ratios measured in samples. Nuclide abundance was so low in these samples, that for seven of the nine ${ }^{10} \mathrm{Be}$ measurements, we could only determine upper limits for ${ }^{10} \mathrm{Be} /{ }^{9} \mathrm{Be}$. For ${ }^{26} \mathrm{Al}$, our sensitivity was higher and finite isotopic ratios $\left({ }^{26} \mathrm{Al} /{ }^{27} \mathrm{Al}\right)$ were measured in five of the nine samples. Upper limits for isotopic ratios were calculated by subtracting the isotopic ratio of the process blank from the measured sample isotopic ratio and propagating the uncertainty quadratically. If the resulting blank-subtracted ratio for a sample was more than the $2 \sigma$ uncertainty, then the ratio was considered finite and the ratio and its uncertainty were reported. If the blanksubtracted ratio was less than the $2 \sigma$ uncertainty, then only

Table 2. Effective exposure age estimates for Crater Lake samples, Baffin Island

\begin{tabular}{|c|c|c|c|c|c|c|c|}
\hline Sample & $\begin{array}{c}\text { Elevation }^{1} \\
\mathrm{~km}\end{array}$ & Sample type $e^{2}$ & Striation or deposition by ${ }^{3}$ & $\begin{array}{c}{ }^{10} \text { Be model age }{ }^{4} \\
\text { kyr }\end{array}$ & $\begin{array}{c}{ }^{26} \text { Al model age } \\
\text { kyr }\end{array}$ & $\begin{array}{l}{ }^{10} \text { Be measured } \\
1^{3} \text { atom g }^{-1}\end{array}$ & $\begin{array}{l}{ }^{26} \text { Al measured } \\
10^{4} \text { atom g }^{-1}\end{array}$ \\
\hline KM95-50 & 0.033 & OC 2, bedrock & Tumbling Glacier & $<1.8$ & $<0.5$ & $<10.9$ & $<1.8$ \\
\hline KM95-51 & 0.033 & OC 2, bedrock & Tumbling Glacier & $<1.6$ & $<0.6$ & $<9.9$ & $<2.4$ \\
\hline KM95-52 & 0.033 & OC 2, cobble & Tumbling Glacier & $<1.1$ & $<0.9$ & $<6.7$ & $<3.3$ \\
\hline KM95-53 & 0.026 & Boulder & Tumbling Glacier & $<3.1$ & $0.9 \pm 0.4$ & $<18.2$ & $3.2 \pm 1.2$ \\
\hline KM95-55 & 0.026 & OC 1, bedrock & Tumbling Glacier & $<2.3$ & $0.8 \pm 0.3$ & $<13.8$ & $2.9 \pm 0.9$ \\
\hline KM95-56 & 0.026 & OC 1, cobble & Tumbling Glacier & $3.0 \pm 0.9$ & $3.2 \pm 1.1$ & $18.1 \pm 3.9$ & $11.9 \pm 3.1$ \\
\hline KM95-57 & 0.064 & Moraine boulder & Tumbling Glacier & $<2.5$ & $0.5 \pm 0.3$ & $<15.4$ & $2.0 \pm 0.9$ \\
\hline KM95-58 & 0.054 & Moraine boulder & Tumbling Glacier & $<3.0$ & $<0.8$ & $<18.9$ & $<3.0$ \\
\hline
\end{tabular}

1 Elevations determined barometrically; all samples exposed at $66^{\circ} \mathrm{N}$.

2 Bedrock samples are from striated roches mountonnées; cobbles sat on the bedrock samples; the boulder sat on unsampled bedrock and the moraine boulders were on the left lateral, Little Ice Age moraine of Tumbling Glacier. Locations of OC 1 and OC 2 (outcrops 1 and 2 ) are shown in Figure 4.

3 Tumbling Glacier flowed nearly perpendicular to Pangnirtung Pass. The Pangnirtung Pass glacier flowed down the U-shaped valley and retreated prior to the last expansion of Tumbling Glacier.

4 Model ages and age limits calculated using production rates of Nishiizumi and others (1989), scaled for current sample-site elevation using neutron-only data from Lal (1991). Uncertainties $(1 \sigma)$ in finite age estimates include AMS counting statistics, $20 \%$ for nuclide production rates, $2 \%$ for total Be and $4 \%$ for total Al.

5 Nuclide abundances and abundance limits calculated from data in Table 1. Uncertainties $(1 \sigma)$ include AMS counting statistics considering blank subtraction, $2 \%$ for total Be and $4 \%$ for total $\mathrm{Al}$. 
an upper limit for the isotopic ratio of the sample could be calculated. Upper limits were calculated by adding the $2 \sigma$ uncertainty to the blank-subtracted ratio. If the blank-subtracted ratio was negative, the $2 \sigma$ uncertainty was considered to be the upper limit. By using a $2 \sigma$ uncertainty, there is a $95 \%$ chance that the actual ratio (and the derived limiting nuclide abundances and limiting model ages) lies below the upper limit we have established.

Abundances and upper limiting abundances for ${ }^{10} \mathrm{Be}$ and ${ }^{26} \mathrm{Al}$ were calculated using measured $\mathrm{Be}$ carrier and native $\mathrm{Al}$ abundances, propagating analytical errors (Table 1). Model exposure ages and upper limits were calculated using the production rates of Nishiizumi and others (1989) for consistency with other published ages and scaled as a function of altitude and latitude, for nucleon abundance only (Lal, 1991). Some recent findings suggest these production rates may be 10 20\% too high (Clark and others, 1995; Bierman and others, 1996). Using lower production rates would systematically increase our model exposure ages by a similar percentage; however, because our samples are from high latitudes $\left(66^{\circ} \mathrm{N}\right)$, nuclide production rates are not time dependent.

Model ages were normalized for sample thickness using an attenuation coefficient of $165 \mathrm{~g} \mathrm{~cm}^{-2}$ and a density of $2.7 \mathrm{~g} \mathrm{~cm}^{-3}$. Correction for topographic shielding was $<5 \%$ for all samples. Bedrock erosion since last exposure has not significantly lowered nuclide abundances because polish and striae are preserved on all bedrock samples. Because annual precipitation is less than $300 \mathrm{~mm}$ and winter winds in Pangnirtung Pass are extreme, significant cosmic-ray shielding by snow cover is unlikely.

\section{RESULTS}

Samples collected from Crater Lake and its adjacent moraines have very low nuclide abundances indicating that any inheritance at this site is, at most, of minor importance (Table 1). Of the 18 analyses we made on nine samples, only seven are finite. The other 11 analyses indicate nuclide abundances low enough that we can only estimate upper limits. Because Baffin Island samples have low native $\mathrm{Al}\left(<140 \mu \mathrm{g} \mathrm{g}^{-1}\right)$ and because our ${ }^{26} \mathrm{Al}$ blanks are lower than our blanks for ${ }^{10} \mathrm{Be},{ }^{26} \mathrm{Al}$ is a more sensitive chronometer than ${ }^{10} \mathrm{Be}$. At this near-sea-level, high-latitude site, we have successfully measured ${ }^{26} \mathrm{Al}$ model ages and set ${ }^{26} \mathrm{Al}$ age limits $<1000$ years (Table 2 ).

\section{Bedrock Samples}

We collected four bedrock samples from two different roches moutonnées, outcrop 1 and outcrop 2 ( $\mathrm{OCl}$ and OC2, Table 2). All samples were striated and polished or grooved by ice flow. Three samples were collected from surfaces where striae indicate that at least some rock had been eroded by Tumbling Glacier (KM95-50, 51 and 55). The fourth sample (KM95-54) had grooves, the direction of which indicated that Tumbling Glacier had not removed any rock from the surface; rather, the KM95-54 surface was molded by ice flowing down Pangnirtung Pass, ice that numerous other cosmogenic ages indicate retreated about 7-8 kyr BP (Davis and others, 1996b; Marsella, 1998).

The three bedrock samples that we collected from roches moutonnées, striated and polished by Tumbling Glacier and recently re-exposed, contain very low levels of ${ }^{10} \mathrm{Be}$ and ${ }^{26} \mathrm{Al}$ (Table 1, KM95-50, 51 and 55; Fig. 4). ${ }^{26} \mathrm{Al}$ data suggest inheritance equivalent to $<800 \mathrm{yr}$ (exposure age and age limits:

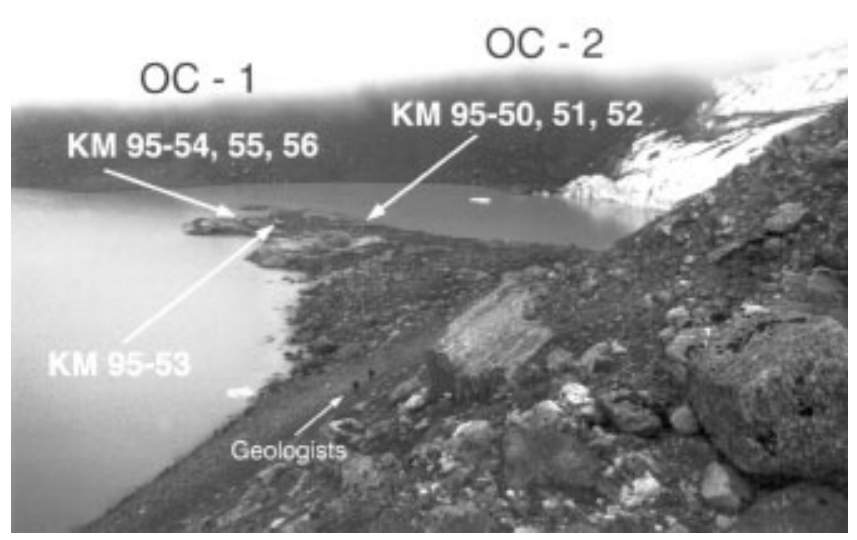

Fig. 4. View south to promontory of roches moutonnées across Crater Lake exposed by retreat of Tumbling Glacier. Sample sites are numbered according to data in Table 1. Note two geologists for scale about halfway down Little Ice Age moraine.

$<500,<600,800 \pm 300$ yr; Table 2); we could not reliably detect ${ }^{10} \mathrm{Be}$ in these samples (exposure age limits: $<1800$, $<1600,<2300$ yr; Table 2).

Only one bedrock sample from a roche moutonnée at Crater Lake (KM95-54; Figs 4 and 5) has striations and

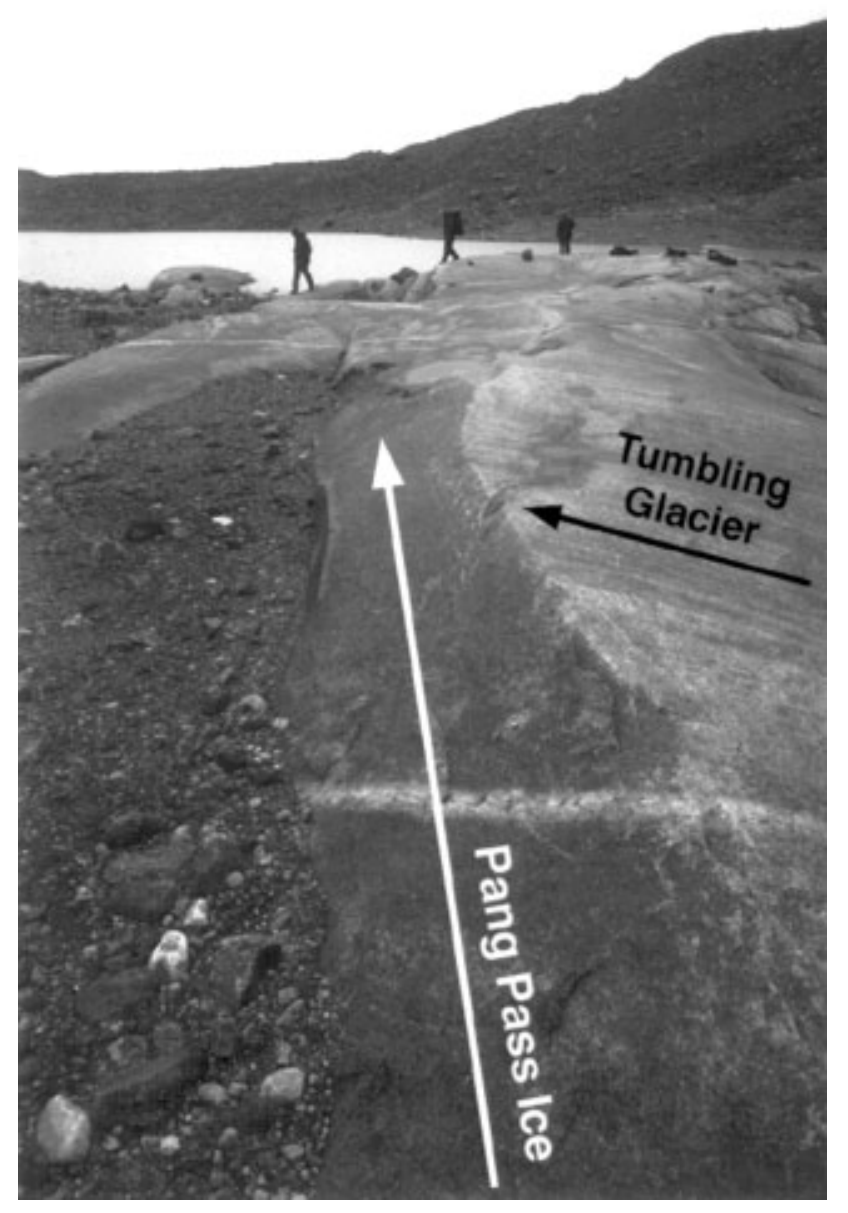

Fig. 5. Roche moutonnée exposed by retreat of Tumbling Glacier, out of view to right. Ice-flow direction on Neoglacial surface ( sample KM95-55) eroded by Tumbling Glacier indicated by black arrow; ice-flow direction on late Wisconsinan surface ( sample KM95-54) eroded by Pangnirtung Pass glacier indicated by white arrow. 
grooves recording ice flow from the large valley glacier occupying Pangnirtung Pass during the late Wisconsinan. This sample, KM95-54, is from the distal side of the same roche moutonnée as sample KM95-55. These earlier grooves and striations, which are nearly perpendicular to the direction of Tumbling Glacier flow, indicate that the Neoglacial ice that overrode outcrop 1 (OCl, Fig. 4) did not remove rock from the distal side; however, the proximal side of this roche moutonnée was eroded sufficiently to remove striations and polish from the Pangnirtung Pass glacier (KM95-55). KM95-54 is the only bedrock sample in which we measured finite abundances for both ${ }^{10} \mathrm{Be}$ and ${ }^{26} \mathrm{Al}$. Both model ages are imprecise and concordant only at $2 \sigma,\left(4000 \pm 1400{ }^{10} \mathrm{Be} \mathrm{yr}\right.$ and $1800 \pm 500{ }^{26} \mathrm{Alyr}$, weighted average $2050 \pm 470 \mathrm{yr}$; Table 2). These values are far less than the late Wisconsinan age of the striae, indicating that the KM95-54 sample site, although not eroded by Tumbling Glacier, was covered with till or ice for much of the Holocene.

Taken together, the bedrock samples from the Crater Lake roches moutonnées suggest that during Neoglaciation at least a meter of bedrock was scoured from surfaces sloping toward Tumbling Glacier. However, the ${ }^{10} \mathrm{Be}$ nuclide abundance for one bedrock surface sloping away from Tumbling Glacier (KM95-54) suggests late Wisconsinan erosion by the valley glacier in Pangnirtung Pass, followed by exposure during the middle part of the Holocene (i.e. about 7.55.5 kyr BP), then burial during Neoglaciation. Burial was probably by Tumbling Glacier ice, and not till, as little till remains on the bedrock peninsula today.

\section{Boulders and cobbles}

We analyzed samples from three boulders, one near Crater Lake between the roches moutonnées (KM95-53; Fig. 4), the other two on a Crater Lake moraine (KM95-57, 58). The morainal boulders may have been exposed for several hundred to a thousand years; the Crater Lake boulder was deposited within the last two decades. We were unable to detect confidently ${ }^{10} \mathrm{Be}$ in any of the boulder samples (exposure age limits: $<3100,<2500,<3000{ }^{10} \mathrm{Be} \mathrm{yr}$; Table 2). ${ }^{26} \mathrm{Al}$ data better constrain the cosmic-ray exposure history of the boulders to the equivalent of $<1000 \mathrm{yr}$ (exposure ages and age limit: $900 \pm 400,500 \pm 300$ and $<800^{26} \mathrm{Al}$ yr; Table 2$)$.

We collected and analyzed cobbles sitting on each of the roches moutonnées (KM95-52 and 56, 0.25 and 0.11 m maximum diameter, respectively; Fig. 4). We were unable to detect either ${ }^{10} \mathrm{Be}(<1100 \mathrm{yr})$ or ${ }^{26} \mathrm{Al}$ ( $<900 \mathrm{yr}$ ) in the larger cobble, implying that the cobble had no significant prior exposure history. The smaller cobble appears to have been exposed to the sea-level, surface equivalent of several thousand years of cosmic-ray bombardment; it has concordant and finite ${ }^{10} \mathrm{Be}$ and ${ }^{26} \mathrm{Al}$ exposure ages of $3000 \pm 900$ and $3200 \pm 1100 \mathrm{yr}$, respectively.

\section{DISGUSSION}

We were not able to detect inherited nuclides in most samples collected from recently deglaciated $(<20 \mathrm{yr})$ bedrock surfaces and from recently deposited ( $<200-1000 \mathrm{yr}$ ) morainal boulders near Crater Lake, Baffin Island. Bedrock surfaces, eroded by Tumbling Glacier and exposed within the last 20 years, have ${ }^{26} \mathrm{Al}$ abundances the equivalent of, at most, $800 \mathrm{yr}$ of surface exposure. Morainal boulders, deposited within the last millennium, have ${ }^{26} \mathrm{Al}$ abundances equivalent to, at most, $900 \mathrm{yr}$ of surface exposure. We could not confidently detect ${ }^{10} \mathrm{Be}$ in any of these recently exposed boulder or bedrock samples.

These very low nuclide abundances support our assumption that concentrations of ${ }^{10} \mathrm{Be}$ and ${ }^{26} \mathrm{Al}$, measured in samples collected from other Baffin Island roches moutonnées, probably reflect exposure ages unbiased by inheritance. Given the small size of Tumbling Glacier, samples that we collected from more than a dozen roches moutonnées along a $100 \mathrm{~km}$ transect from the crest of Pangnirtung Pass to the mouths of Pangnirtung and Kingnait Fiords (Fig. 1) probably inherited a low abundance of cosmogenic nuclides, considering the size of the late Wisconsinan valley glacier that eroded these features (Davis and others, 1996a, b). In this Arctic fiord environment, glacial erosion has apparently been sufficient to remove material significantly dosed by cosmic radiation during interglacials or interstadials. In the lower elevations of Pangnirtung Fiord, glacial erosion seems likely to have "reset" cosmogenic clocks to near zero by the time ice melted away exposing the outcrops.

The two cobbles we sampled have different exposure histories. In one cobble, we could detect neither ${ }^{10} \mathrm{Be}$ nor ${ }^{26} \mathrm{Al}$, implying that, at most, the cobble has an effective exposure age $<900$ yr. In the other cobble, we confidently detected both ${ }^{10} \mathrm{Be}$ and ${ }^{26} \mathrm{Al}$; this cobble carries a significant inheritance (about $3000 \mathrm{yr}$ ) and, if collected to date a Holocene or late Pleistocene deposit, would result in an erroneous age assignment. We collected the cobble near sea level and have used sea-level nuclide production rates to estimate inheritance in terms of exposure duration. However, the cobbles and the boulders discussed above were likely transported from the accumulation zone of Tumbling Glacier, about $1000 \mathrm{~m}$ a.s.l., where production rates are higher by a factor $\geq 2.5$. If this were the case, then the nuclide abundances we measured would reflect about $1000 \mathrm{yr}$ of surface exposure at high elevation.

Sample KM95-54, the bedrock surface recently uncovered by retreat of Tumbling Glacier ice, but retaining its original down-valley ice-flow indicators, allows us to estimate crudely the total duration of Neoglacial ice cover. This sample-site surface was shaped by ice flowing down Pangnirtung Pass and Fiord, ice that numerous other cosmogenic ages indicate retreated from $7000-8000{ }^{10} \mathrm{Be}:{ }^{26} \mathrm{Al} y r$ ago (Davis and others, 1996a, b; Marsella, 1998). At some time(s), probably during the mid- to late Holocene, the sample site was overrun, but not eroded by ice of Tumbling Glacier. If we assume deglaciation by Pangnirtung Pass ice at $7500 \pm 500{ }^{10} \mathrm{Be}:{ }^{26} \mathrm{Al}$ yr and a weighted average ${ }^{10} \mathrm{Be}:{ }^{26} \mathrm{Al}$ exposure of KM95-54 for $2050 \pm 470 \mathrm{yr}$, then Neoglacial Tumbling Glacier ice expanded in Pangnirtung Pass and overran site KM95-54 for a total of about $5450{ }^{10} \mathrm{Be}:{ }^{26} \mathrm{Al}$ yr. Numerous other lines of evidence, described earlier, support Neoglaciation lasting 4000-5000 yr in the Pangnirtung Pass area (Davis, 1980, 1985, 1987).

Although Jahns (1943), Hallet $(1979,1996)$ and Sugden and others (1992) have contributed to our understanding of the glacial origin of stoss-and-lee topography, including roches moutonnées, the magnitude and rate of glacial erosion of stoss-and-lee bedrock forms have been difficult to quantify until recently. Briner and Swanson (1998) used cosmogenic ${ }^{36} \mathrm{Cl}$ in samples collected from a glacially eroded bedrock form in the Puget Lowland to calculate glacial erosion rates of the Cordilleran ice sheet during the last glaciation (about 3 calendar kyr of ice cover). They estimated glacial abrasion rates of $0.09-0.35 \mathrm{~mm} \mathrm{a}^{-1}$ for the stoss side, 
$0.63-0.72 \mathrm{~mm} \mathrm{a}^{-1}$ for summit surfaces and $0.13-0.28 \mathrm{~mm} \mathrm{a}^{-1}$ for the lee side above the quarried zone.

Using data for samples KM95-50, 51 and 55, we can estimate a lower limit for the rate of glacial erosion by Tumbling Glacier at Crater Lake (Table 3). We calculate that samples KM95-50, 51 and 55 had $2050 \pm 470$ yr of early Holocene exposure (considering KM95-54 and other similar age estimates for the duration of Neoglaciation) before being covered and eroded by Tumbling Glacier for a total of about $5450 \mathrm{yr}$ (7500 yr minus $2050 \mathrm{yr}$ ). Assuming production rates of Nishiizumi and others (1989), these three samples would have contained $12300 \pm 3000$ atoms $\mathrm{g}^{-1}$ of ${ }^{10} \mathrm{Be}$ and $74000 \pm 17000$ atoms $\mathrm{g}^{-1}$ of ${ }^{26} \mathrm{Al}$ just before they were overwhelmed by the advancing Tumbling Glacier ice. Using the measured nuclide abundances and abundance upper limits, in conjunction with the depth-production rate model (Equation (1)), we can calculate lower limits for the rate of glacial erosion (Table 3 ).

$$
x=-\frac{\Lambda}{\rho} \ln \left(\frac{N_{\mathrm{m}}}{N_{0}}\right)
$$

$x$ is the depth of rock eroded $(\mathrm{cm}), \Lambda$ the neutron absorption coefficient $\left(165 \mathrm{~g} \mathrm{~cm}^{-2}\right), \rho$ the rock density $\left(2.7 \mathrm{~g} \mathrm{~cm}^{-3}\right), N_{\mathrm{m}}$ the measured nuclide abundance or abundance limit (atoms $\mathrm{g}^{-1}$ ) and $N_{0}$ is the pre-erosion nuclide abundance $\left(\right.$ atoms $\mathrm{g}^{-1}$ ).

Table 3. Erosion rates calculated for bedrock outcrops, Crater Lake, Baffin Island

\begin{tabular}{|c|c|c|c|}
\hline Sample & $\begin{array}{l}{ }^{26} \text { Al measured } \\
10^{4} \text { atom }^{-1}\end{array}$ & $\begin{array}{c}\text { Erosion } \\
\mathrm{m}\end{array}$ & $\begin{array}{c}\text { Erosion rate }^{2} \\
\mathrm{~mm} \mathrm{a}^{-1}\end{array}$ \\
\hline KM95-50 & $<1.8$ & $>0.86$ & $>0.16$ \\
\hline KM95-51 & $<2.4$ & $>0.69$ & $>0.13$ \\
\hline KM95-55 & $2.9 \pm 0.9$ & $0.57 \pm 0.18$ & $0.10 \pm 0.03$ \\
\hline
\end{tabular}

\footnotetext{
1 Calculated using Equation (1) and propagating only analytical error for ${ }^{26} \mathrm{Al}$ abundance measurement.

2 Calculated assuming $5450 \mathrm{yr}$ of burial and erosion by Tumbling Glacier.
}

Because five of the six pertinent isotopic analyses only gave upper limits, we can calculate only one finite erosion rate. Based on ${ }^{26} \mathrm{Al}$ abundance, Tumbling Glacier eroded rock from site KM95-55 at an average rate of $0.10 \pm 0.03 \mathrm{~mm} \mathrm{a}^{-1}$. Using upper limits of ${ }^{26} \mathrm{Al}$ abundance for sample sites KM9550 and 51, we calculate that glacial erosion proceeded at average rates $>0.16$ and $>0.13 \mathrm{~mm} \mathrm{a}^{-1}$, respectively. Because we are less capable of detecting low levels of ${ }^{10} \mathrm{Be}$ in our samples, the upper limits of ${ }^{10} \mathrm{Be}$ concentration provide less-useful limits on glacial-erosion rates. However, conclusions reached from Be data are fully consistent with erosion rates calculated from ${ }^{26} \mathrm{Al}$ measurements.

Our estimates of Neoglacial erosion rates of Tumbling Glacier are greater than those determined for 10 cirque glaciers in the Pangnirtung Fiord area by Anderson (1978), who used estimates for volumes and ages of till in ice-cored moraines to calculate erosion rates of $0.008-0.076 \mathrm{~mm} \mathrm{a}^{-1}$. Our Neoglacial erosion rates are also greater than those determined by Marsella (unpublished data), who estimated volumes of silt accumulated in radiocarbon-dated sediment cores from a small lake down-valley from a cirque glacier near Pangnirtung Fiord (Davis and Kihl, 1985) to calculate erosion rates of $0.0016-0.040 \mathrm{~mm} \mathrm{a}^{-1}$. However, our esti- mates of Neoglacial abrasion rates are generally less than those determined by Briner and Swanson (1998) for the Cordilleran ice sheet in the Puget Lowland.

\section{GONGLUSIONS}

Eighteen AMS analyses, made on samples collected from a landscape recently exposed by ice retreat, allow us to make four conclusions:

(1) Bedrock surfaces, striated and polished by Tumbling Glacier for several thousand years, contain very low levels of ${ }^{10} \mathrm{Be}$ and ${ }^{26} \mathrm{Al}$, equivalent to $800 \mathrm{yr}$ or less of surface exposure. This finding suggests that glacially molded bedrock surfaces in the Pangnirtung Pass and Fiord area are reasonable sites for sampling and cosmogenic dating, as inheritance of cosmogenic nuclides from prior exposure near Tumbling Glacier was minimal.

(2) Boulders sampled from the lateral moraine of Tumbling Glacier contain little ${ }^{10} \mathrm{Be}$ or ${ }^{26} \mathrm{Al}$. Effective ${ }^{26} \mathrm{Al}$ exposure ages are $<800$ yr. Such low nuclide abundances imply that inheritance is unimportant for these boulders. One cobble, perched on a roche moutonnée, had the equivalent of several thousand years of surface exposure, suggesting that cobbles may be more likely than boulders to carry a significant inheritance of cosmogenic nuclides from prior exposure.

(3) Tumbling Glacier eroded competent, quartz-rich, gneissic bedrock at $>0.10 \mathrm{~mm} \mathrm{a}^{-1}$. This erosion rate is preliminary because only one sample was available for an estimate of ice-cover duration; however, this estimate is consistent with other evidence and the erosion-rate calculation is within the range of rates determined for the much-larger Cordilleran ice sheet in Washington State.

(4) Our data demonstrate that it is possible to measure finite ${ }^{26} \mathrm{Al}$ ages near sea level and at high latitudes in samples as young as $500 \mathrm{yr}$. To achieve such low detection limits, purified quartz must contain low levels of ${ }^{27} \mathrm{Al}$. Detection limits of ${ }^{10} \mathrm{Be}$ could be reduced by the use of lowerlevel carriers and larger sample sizes.

\section{AGKNOWLEDGEMENTS}

We thank P. Hackett, C. Killian, J. Leonard, C. Massey, J. Turner and staff of the Canadian Parks Service for field assistance; R. Finkel, Center for Accelerator Mass Spectrometry (LLNL), for laboratory assistance; and M. Kaplan, University of Colorado, D. Fabel, Purdue University, C. D. Clark, University of Sheffield and two anonymous reviewers for comments that improved the manuscript. The project was funded by U.S. National Science Foundation grant OPP-93-21733 to P.T. D. and P. R. B, with additional support from the American Association of Petroleum Geologists to K. A. M. Part of this work was supported under the auspices of the U.S. Department of Energy to LLNL under contract W-7405-ENG-48.

\section{REFERENGES}

Abbott, M. B. and T.W. Stafford, Jr. 1996. Radiocarbon geochemistry of modern and ancient Arctic lake systems, Baffin Island, Canada. Quat. Res., 45(3), 300-311.

Anderson, L.W. 1978. Cirque glacier erosion rates and characteristics of 
Neoglacial tills, Pangnirtung Fjord area, Baffin Island, N.W.T., Canada. Arct. Alp. Res., $10(4), 749-760$.

Andrews, J.T. 1975. Support for a stable Late Wisconsin ice margin (14,000 to 9000 B.P.): a test based on glacial rebound. Geology, 3(11), 617-620.

Andrews, J. T. 1987. The Late Wisconsinan glaciation and deglaciation of the Laurentide ice sheet. In Ruddiman, W. F. and H. E. Wright, Jr, eds. North America and adjacent oceans during the last deglaciation. Boulder, CO, Geological Society of America, 13-37. (The Geology of North America K-3.)

Andrews, J.T. and D. M. Barnett. 1979. Holocene (Neoglacial) moraine and proglacial lake chronology, Barnes Ice Cap, Canada. Boreas, 8(3), 341-358.

Andrews, J.T., W. N. Mode and P. T. Davis. 1980. Holocene climate based on pollen transfer functions, eastern Canadian Arctic. Arct. Alp. Res., 12(1), $41-64$.

Andrews, J.T., P.T. Davis, W. N. Mode, H. Nichols and S. K. Short. 1981. Relative departures in July temperatures in northern Canada for the past 6,000 yr. Nature, 289 (5794), 164-167.

Andrews, J.T., H. Erlenkeuser, K. Tedesco, A. E. Aksu and A. J.T. Jull. 1994. Late Quaternary (stage 2 and 3) meltwater and Heinrich events, northwest Labrador Sea. Quat. Res., 41(1), 26-34.

Andrews, J. T. and 7 others. 1995. A Heinrich-like event, H-0 (DC-0) source(s) for detrital carbonate in the North Atlantic during the Younger Dryas chronozone. Paleoceanography, 10(5), 943-952.

Bierman, P. R. and A. R. Gillespie. 1995. Geomorphic applications of in situproduced cosmogenic isotopes. Boulder, CO, Geological Society of America. (Short Course Manual.)

Bierman, P. R., P. Larsen, E. Clapp and D. Clark. 1996. Refining estimates of ${ }^{10} \mathrm{Be}$ and ${ }^{26} \mathrm{Al}$ production rates. Radiocarbon, $\mathbf{3 8}(\mathrm{l}), 149$.

Bierman, P. R., K.A. Marsella, C. Patterson, P.T. Davis and M. Caffee. 1999. Mid-Pleistocene cosmogenic minimum-age limits for pre-Wisconsinan glacial surfaces in southwestern Minnesota and southern Baffin Island: a multiple nuclide approach. Geomorphology, 27, 25-39.

Briner, J. P. and T.W. Swanson. 1998. Using inherited cosmogenic ${ }^{36} \mathrm{Cl}$ to constrain glacial erosion rates of the Cordilleran ice sheet. Geology, 26(1),3-6.

Clark, D. H., P. R. Bierman and P. Larsen. 1995. Improving in situ cosmogenic chronometers. Quat. Res., 44(3), 367-377.

Davis, P.T. 1980. Late Holocene glacial, vegetational and climatic history of Pangnirtung and Kingnait Fiord area, Baffin Island, N.W.T., Canada. (Ph.D. thesis, University of Colorado, Boulder.)

Davis, P. T. 1985. Neoglacial moraines on Baffin Island. In Andrews, J. T., ed. Quaternary environments: eastern Canadian Arctic, Baffin Bay and western Greenland. London, Allen and Unwin, 682-718.

Davis, P. T. 1987. Guidebook to the glacial geology of Pangnirtung Pass, southern Cumberland Peninsula, Baffin Island. Ottawa, Ont., International Union for Quaternary Research. XIIth International Congress, 31 July-9 August 1987. (Field Trip C.1.)

Davis, P.T. andJ. A. Fabel. 1988. Lichenometric dating of debris flow levees, Pangnirtung Pass, Baffin Island: additional data and new interpretations. Geol. Soc. Am. Abstr. Programs, 20 (7), 14-15.

Davis, P.T. and R. Kihl. 1985. Late Holocene record of debris avalanche deposits interbedded with lake sediments, Baffin Island, Canada. Geol. Soc. Am. Abstr. Programs, 17 (1), 14

Davis, P.T. and 6 others. 1995. Timing and extent of glaciation on southern Baffin Island, Nunavut Territory, Arctic Canada, using in situ cosmogenic isotopes. Geol. Soc. Am. Abstr. Programs, 27(6), A60.

Davis, P.T., K. A. Marsella, P. R. Bierman and M.W. Caffee. 1996a. Deglacial dynamics of Baffin Island by cosmogenic exposure dating. Geol. Soc. Am. Abstr. Programs, 28 (7), A434.

Davis, P. T., K. A. Marsella, P. R. Bierman and M.W. Caffee. 1996b. Paired glacial boulder and bedrock cosmogenic analyses. [Abstract.] EOS, 77(46), Fall Meeting Supplement, F193.

Denton, G. H. and T. J. Hughes, eds. 1981. The last great ice sheets. New York, etc., John Wiley and Sons.

Dyke, A. S. 1977. Quaternary geomorphology, glacial chronology and climatic and sea-level history of southwestern Cumberland Peninsula, Baffin Island, Northwest Territories, Canada. (Ph.D. thesis, University of Colorado, Boulder.)

Dyke, A. S. 1979. Glacial and sea-level history of southwestern Cumberland Peninsula, Baffin Island, N.W.T., Canada. Arct. Alp. Res., 11 (2), 179-202.

Dyke, A. S. and V. K. Prest. 1987. Late Wisconsinan and Holocene history of the Laurentide ice sheet. Géogr. Phys. Quat., 41 (2), 237-263.

Dyke, A. S., J.T. Andrews and G. H. Miller. 1982. Quaternary geology of Cumberland Peninsula, Baffin Island, District of Franklin. Geol. Surv. Can. Mem. 403.

Hallet, B. 1979. A theoretical model of glacial abrasion. f. Glaciol., 23(89),
39-50.

Hallet, B. 1996. Glacial quarrying: a simple theoretical model. Ann. Glaciol., 22, 1-8.

Hughes, T. J., G. H. Denton and M. G. Grosswald. 1977. Was there a lateWürm Arctic ice sheet? Nature, 266 (5603), 596-602.

Ives, J. D. 1978. The maximum extent of the Laurentide ice sheet along the east coast of North America during the last glaciation. Arctic, 31 (1), 24-53.

Jahns, R. H. 1943. Sheet structure in granites: its origin and use as a measure of glacial erosion in New England. f. Geol., 51, 71-98.

Jennings, A. E. 1993. The Quaternary history of Cumberland Sound, southeastern Baffin Island: the marine evidence. Géogr. Phys. Quat., 47(1), 21-42.

Jennings, A. E., K. A. Tedesco, J.T. Andrews and M. E. Kirby. 1996. Shelf erosion and glacial ice proximity in the Labrador Sea during and after Heinrich events ( $\mathrm{H}-3$ or 4 to $\mathrm{H}-0)$ as shown by foraminifera. In Andrews, J.T., W. E. N. Austin, H. Bergsten and A. E. Jennings, eds. Late Quaternary palaeoceanography of the North Atlantic margins. Bath, Geological Society, 24-49.

Kohl, G. P. and K. Nishiizumi. 1992. Chemical isolation of quartz for measurement of in-situ-produced cosmogenic nuclides. Geochim. Cosmochim. Acta, 56, 3583-3587.

Lal, D. 1991. Cosmic-ray labeling of erosion surfaces: in situ nuclide production rates and erosion models. Earth Planet. Sci. Lett., 104, 424-439.

Lemmen, D. S., R. Gilbert, J. P. Smol and R. I. Hall. 1988. Holocene sedimentation in glacial Tasikutaaq Lake, Baffin Island. Can. 7. Earth Sci., 25(6), 810-823.

Mann, M. E., R. S. Bradley and M. K. Hughes. 1998. Global-scale temperature patterns and climate forcing over the past six centuries. Nature, 392(6678), 779-787.

Marsella, K. A. 1998. Timing and extent of glaciation in the Pangnirtung Fiord region, Baffin Island: determined using in situ produced cosmogenic ${ }^{10} \mathrm{Be}$ and ${ }^{26} \mathrm{Al}$. (M.Sc. thesis, University of Vermont.)

Marsella, K. A., P.T. Davis, P. R. Bierman, R. C. Finkel, M.W. Caffee and J. R. Southon. 1995. Geologic test of weathering zone concept and nunatak hypothesis using cosmogenic isotope dating in Pangnirtung Fjord area, Baffin Island, Nunavut Territory, Canada. Geol. Soc. Am. Abstr. Programs, 27(6), A59.

Marsella, K. A., P. R. Bierman, P.T. Davis and M.W. Caffee. 1996. Stage II "Big Ice" on Baffin Island. Geol. Soc. Am. Abstr. Programs, 28(7), A433-A434.

Mayewski, P. A., G. H. Denton and T. J. Hughes. 1981. Late Wisconsin ice sheets of North America. In Denton, G. H. and T. J. Hughes, eds. The last great ice sheets. New York, etc., John Wiley and Sons, 67-178.

Miller, G. H. 1973. Late Quaternary glacial and climatic history of northern Cumberland Peninsula, Baffin Island, N.W.T., Canada. Quat. Res., 3(4), 561-583.

Miller, G. H. and J.T. Andrews. 1972. Quaternary history of northern Cumberland Peninsula, east Baffin Island, N.W.T., Canada. Part VI. Preliminary lichen growth curve for Rhizocarpon geographicum. Geol. Soc. Am. Bull., 83(4), 1133-1138.

Miller, G. H. and A. S. Dyke. 1974. Proposed extent of Late Wisconsin Laurentide ice on eastern Baffin Island. Geology, 2(3), 125-130.

Nishiizumi, K. and 6 others. 1989. Cosmic ray production rates of ${ }^{10} \mathrm{Be}$ and ${ }^{26} \mathrm{Al}$ in quartz from glacially polished rocks. 7. Geophys. Res., 94(B12), 17,907-17,915.

Short, S. K., W. N. Mode and P.T. Davis. 1985. The Holocene record from Baffin Island: modern and fossil pollen studies. In Andrews, J.T., ed. Quaternary environments: eastern Canadian Arctic, Baffin Bay and western Greenland. London, Allen and Unwin, 608-642.

Sugden, D. E. 1977. Reconstruction of the morphology, dynamics and thermal characteristics of the Laurentide ice sheet at its maximum. Arct. Alp. Res., 9(1), 21-47.

Sugden, D. E. and S. H. Watts. 1977. Tors, felsenmeer, and glaciation in northern Cumberland Peninsula, Baffin Island. Can. 7. Earth Sci, 14(12), 2817-2823.

Sugden, D. E., N. Glasser and C. M. Clapperton. 1992. Evolution of large roches moutonnées. Geogr. Ann., 74A(2-3), 253-264.

Thompson, H. R. 1957. The old moraines of Pangnirtung Pass, Baffin Island. 7. Glaciol., 3(21), 42-49.

Wolfe, A. P. 1996. A high-resolution late-glacial and early Holocene diatom record from Baffin Island, eastern Canadian Arctic. Can. 7. Earth Sci., $33(6), 928-937$.

Wolfe, A. P. and J.W. Härtling. 1996. The late Quaternary development of three ancient tarns on southwestern Cumberland Peninsula, Baffin Island, Arctic Canada: paleolimnological evidence from diatoms and sediment chemistry. f. Paleolimnol., 15(1), 1-18. 